\title{
An Evaluation on the Regression Level of Prospective Teachers' Metacognitive Skills in terms of their Community Service Activities Perceptions
}

\author{
Metin Kartal", Özden Demir, Halil İbrahim Kaya \\ Department of Education Sciences, Kafkas University, Turkey
}

Copyright $(2017$ by authors, all rights reserved. Authors agree that this article remains permanently open access under the terms of the Creative Commons Attribution License 4.0 International License

\begin{abstract}
Metacognition, thinking, and learning are a continuous transformation in case of different aspects of the same event. In turn, metacognition is an inseparable part of the process of thinking to think. Recently, the definition of metacognition has been elaborated. And as defined in the past, it has only consisted of "thinking on think", but now it covers of awareness of one's own knowledge, cognitive steps, cognitive and effective situations, intentional and awareness monitoring ability, and regulating his/herself knowledge, as well. In such a process, social awareness and social dimensions of development thinking in the participants' individual learning and language are an inevitable necessity and the key to thinking rather than effective think. In this line, individuals are also supposed to effectively use the cognitive processes and skills. Herewith, metacognition could be accepted as a large structure consisting of the community service activities. As research findings also revealed, the teachers' participation in community service activities is being effective for the development of cognitive skills and higher-level thinking processes; in this regard, as it contribute the teachers' development of the responsibility for their own learning, it has positively contributed that the more their necessary skills increased, the more positive attitude toward student the teachers have. To determine the prospective teachers' personal traits, the perception on Community Service Activities, and to measure the cognitive skills respectively in this research, it was used "Personal Information Form"; "Community Service Activities Scale", and "Cognitive Awareness Scale". Las but not least, the overall aim of this study is to uncover what extent the prospective teacher's cognitive skills is predicted in terms of the variables of Community Service Activities Perception Scale.
\end{abstract}

Keywords Metacognitive Awareness, Community Service Activities, Thinking

\section{Introduction}

\subsection{A Pattern for Metacognitive Awareness and Community Service Activities}

As is seemed in many research fields of cognitive development, the history of it mainly has been began with Piaget (Flavell [15]; Flavell \& Miller [16]; Shantz, [41]). A central Piagetian approach is that children begin their development by being cognitively egocentric (Flavell [15]). Piaget et al. used egocentrism and other related concepts to interpret their developmental studies of a wide variety of social-cognitive topics: perceptual perspective taking; egocentric communication; the misattribution of mental characteristics to physical objects (animism) physical characteristics to mental events (realism); understanding of thoughts, dreams, intentions, and morality (Flavell, Green, \& Flavell, [17]; Woolley \& Boerger [45]). Another wave of theory and research in this general area was elaborated with the extensive work on metacognitive development that began in the early 1970s. In fact, metacognition -that is, cognition that reflects on, monitors, or regulates first-order cognitionwas characterized by Flavell [20] as a "promising new area of investigation.

Surveys of this elaborated and large literature include Brown, Bransford, Ferrara, and Campione [5], Flavell, Miller, and Miller [19], Kuhn [28], Moshman [34], and Schneider and Bjorklund [44]. Metacognition (cognition about cognition-hence the meta-) has been defined as any knowledge or cognitive activity that takes as its object, or regulates, any aspect of any cognitive activity (Flavell, Miller, \& Miller [19]). Drawing upon the literature, we have found that the majority of carried out studies classified under metacognitive/metacognition have investigated children's meta-memory - that is, their knowledge about variables affecting memory performance and, especially, their knowledge and use of memory strategies. However, the term has also been used and studied in the numerous studies 
consisting of children's cognition regarding comprehension, communication, language, perception, attention, and problem solving.

Metacognitive awareness, thinking, and learning are a continuum transformation in case of different aspects of the same event. For this point, metacognition is an inseparable part of the thinking to think process. Metacognition term has been coined as different definitions in the body of literature. Demirel [11], Erden and Akman [14] defined this term as cognitive information, Açıkgöz [1], Namlu [31], Çetinkaya [7] as metacognitive, Doğanay [12] and Demir [8] as metacognitive awareness. Metacognition is defined as thinking to think.

Individuals reflect and evaluate their thinking processes, by which they could better control and manipulate one's thinking and feeling processes. Recently, the definition of metacognition has been elaborated, and as defined in the past, it has only consisted of "thinking on think", but now it covers awareness of one's own knowledge, cognitive steps, cognitive and effective situations, intentional and awareness monitoring ability, and regulate his/herself knowledge, as well. Kluwe (1982, cited by Louca [30]) brought further definition to the concept of metacognition, describing activities referred to as metacognition:

1. the thinking subject has some knowledge about his own thinking and that of other persons; and

2. the thinking subject may monitor and regulate the course of his own thinking, i.e. may act as the causal agent of his own thinking'

A learning-centered approach to teaching inevitably not only requires the learner in the learning process itself, but also requires teachers to be highly competent with well-developed teaching, skills, and critical thinking skills guiding their behavior in order to recognize these qualities in their students. Teachers' critical thinking skills are one important way through which teachers could help students learn and explain how and why they achieved this progress, and talk about their feelings. Such skills like planning, problem solving, self-regulation, and learning to control the lessons do give teachers a level of cognitive awareness that has become a necessity for good education. In such a learning-centered approach, the learner becomes more independent, and the teacher steadily gains skills as a cognitive coach.

Thinking process takes place in every stage of learning and in turn reflects students' behaviors. Acquisition is a thinking system, which is the act of step-by-step planning what should be done, and is, therefore, the monitoring; thereby is the active participation of the learners in their own learning by interacting with the environment, evaluating every phase, and controlling their learning process accordingly (Doğanay [12]).

Drawing upon the literature, we found that the process and abilities of critical thinking and metacognition in curriculum are two important aspects for teachers to boost a meaningful learning, obtain the reasoned judgments abilities in the dynamic structure of learning (Nielsen [32]; Y1lmaz [52];
Demir [8]; Lee, Teo and Chai [29], Semerci and Elaldı [40]; Özsoy and Günindi [35]; Pinto, Iliceto, Melogno [36]; Demir [9]).

During this process, the social awareness and development dimensions are important facts for a learning-individual to participate in civic as specifically contextualized knowledge to specific events. Using language is a key to the effective thinking. If there are an individual phenomenon, concept, rich generalizations, and its quality, this, in turn, affects one's skills to have a higher order thinking. In this context, one could better use the process and abilities of metacognitive awareness, as well. Social processes and services have a discernible impact on the development of one's intellectual language concepts. So, community service activities are good practicums, which stand important for improving one's intellectual language, culture and metacognitive process, and skills.

The conceptualization of community service activities was increasingly developed to meet the educational expectations of the students with their publics. Within this scope, these activities could be evaluated to create a fruitful opportunity and first-hand experiencing of public and its societal individuals, and offers them to experience the expected world beyond the classroom.

Community service could be interwoven into the university environment through the integration of service-learning in faculty classrooms (Zlotkowski, 1996; cited by Shiarella, Mccarthy and Tucker [42]). Service-learning is an experiential pedagogy requiring students to apply course theory by participating in a project for a non-profit organization so as to turn their theoretical knowledge into practice. Educators, researchers, and policy makers believe that community service activities provide valuable experiences and learning environment for students (Nathan and Kielsmeier, 1991; cited by Shiarella, Mccarthy and Tucker [42]). In the form of service-learning, community service presents an opportunity for students to improve numerous skills, including team building, leadership, conflict resolution, communication, organization, and time management (Tucker, McCarthy, Hoxmeier and Lenk, 1998).

The researches have documented that after participating in community service activities, students are able to be more addicted to their professions and interested in learning, more well-informed. These have developed both their personal and community communication skills; consequently increased the level of participation in communal engagement activities (Bringle and Hatcher [6]; Draper [13]; Hatcher-Skeers and Aragon [24]; Kalivas [27]).

In studies regarding Community Service Activities, it was found that it was generally carried out in terms of different dimensions by Turkish scholars. Based on the national researches, it was found that Y1lmaz [53] carried out a study on "social responsibility"; Sönmez [43] on "Social studies teachers' attitudes towards public service applications"; Elma et al. [15] on "Course in candidate teachers' perceptions of community services"; Uğurlu and Kıral [50] 
on "Prospective teachers of the course, its processes and its applications in service to the community views on the achievements"; Saran, Coşkun, İnal, Zorel, and Aksoy [38] on "responsible for the development of social awareness in universities hood"; Ögülmüş [37] on "contribution of education faculties to social life in the context of community service"; Gökçe [22] on "social sciences teachers' reviews on the applications of community service"; Horzum and Bektaş [25] on "authentic learning community service and satisfaction lesson are teachers' attitudes toward impact of course".

In international researches; it was pointed out that an explanatory method design carried out by Simons and Cleary (2006) being used to evaluate the influence of a service-learning course over learning, personal, and social outcomes for students' participating in service-learning activities. These students have showed developments in their scores in terms of diversity and political awareness, community self-efficacy, and civic engagement from the beginning to the end of the semester. Additionally, the students' academic learning, personal and interpersonal development, and community engagement were determined as the major benefits from participating in service-learning. The findings of this study have suggested that service-learning contributes to students' academic learning, personal, and social development by means of social-emotional processes.

Based on the results of some researches referred to Community Service Activities; all studies could be summarized as follows: Klute and Billig (2002) found out that these activities increased social, cognitive, and interpersonal skills; Billig, Meyer, and Hofschire (2003) made connections to their community and cultural heritage; Melchior and Bailis (2002) increased civic engagement knowledge and awareness of societal issues; Eyler, Root and Giles (1999) improved moral reasoning and problem solving; Stewart [45]; Stewart and Bai [46] demonstrated more respectful and caring attitudes toward diverse groups; Billig, Root, and Jesse (2005) enhanced civic engagement and political efficacy; Kahne and Westheimer (2006) achieved a sense of civic efficacy; Youniss, McLellan, and Yates (1997) increased longitudinal civic participation; Althof and Berkowitz (2006) developed participatory competence - the skills and abilities needed for civic participation; Eyler et al., (2001) showed practical understanding of theories and enhanced ability to connect academic learning to societal issues and concerns (cited by Stewart, 2012: p. 28).

In the national literature reviews; it was not found any researches referred to both community service activities and metacognitive awareness together. This lack of correlation between Metacognitive Awareness and Community Service Activities guides us a brand new research proposal. While skimming the literature: it was found a well-known term: Depth of Learning. This term is depended upon "Bloom's Taxonomy of Educational Objectives [4]", which explains learning as a hierarchical sequence moving from the lower-order (identify, describe, apply) to the higher-order skills (analyze, synthesize, evaluate). From an important premise of Bloom [4]'s work; it could be correlated between these important patterns to master the students before passing to the next level. In this framework, community service activities could build a bridge for the students in identifying their learning objectives, describing students' do's and don'ts via prompting questions and allowing students to the experiential assessment of their reflections by using Metacognitive Awareness, that is to say, constructing students' lower-order skills (identify, describe, apply) via Community Service Activities, and in turn preparing them to progress to the next level. In this context, candidate teachers all should be informed about the benefits of community service activities so as to better enhance their inter-community communications and to be a well-learner and an effective designer of the learning environment. In this approach, metacognitive awareness will embrace in detail the community service activities.

As the findings of this study; teacher's participation in community service activities will improve his/her skills and strategies of metacognitive awareness and metacognitive thinking; in turn this will contribute the candidate teachers' own responsibilities, and the more necessary skills and strategies are developed, the better learned teachers will be a figure to their students. Moreover, it was not found any researches analyzing the correlation between metacognitive awareness and community service practices. The aim of this study was to analyze the correlation between metacognitive skills and strategies necessary for teachers and community service activities. The main purpose of this study was to analyze the regression level of prospective teachers' metacognitive skills in terms of their community service activities perceptions. In this framework, the following questions were tried to be answered.

1. Do the community service activities perceptions of prospective teachers significantly explain their metacognitive awareness skill?

2. Which variables of community service activities perception scale (CSAS) do more explain the metacognitive awareness skill of prospective teachers?

\section{Materials and Methods}

This study is a procedural research in relational research model. Procedural three types of research provide us with information: (1) The criterion of predictability of behavior patterns, (2) The criterion of determining which behavior patterns, (3) Criteria to be associated as the received test patterns of behavior or procedural validity of the tests (Borg and Gall [3]). This measures cognitive skills in research behavior patterns, taken as a dependent variable, in other words practices and perceptions of the public service were identified as predictor variables.

\subsection{Population and Sampling}

The population of the study is the teacher candidates studying in Departments of Science and Psychological Counselling and Guidance Teaching in the academic year 
2014-2015, Faculty of Education, Kafkas University. This is not based on probability while determining the universe cluster sampling method with 100 teachers in the sampling. 56 of sampling, while 44 of them in the normal education, continue to secondary education; 50 female and 50 male; 50 from Counselling and Guidance Teaching and 50 from Science, 67 students stated to have participated in any social activities; 33 of them states that students are participating in any social activity.

\subsection{Data Collection}

"Personal Information Form" was used to determine the personal characteristics of the teacher candidates; "Community Service Activities Perception Scale" was used so as to determine the perception of community service activities, and "Metacognitive Awareness Scale (MAS)" was used to measure the cognitive skills.

\subsection{1. "Personal Information Form"}

Personal Information Form was used to collect data about the scale of the arguments and sample developed by researchers to describe in terms of personal characteristics. There are seven questions about the education level and the number of weekly book and magazine reading form the type of education, class, division, gender, education level of the mother, father.

\subsubsection{Metacognitive Awareness Scale (MAS)}

The Metacognitive Awareness Scale (MAS) was developed by Demir [9] with a view to identifying the level of metacognition skills of prospective teachers. For the MAS, $\mathrm{KMO}=.914$; Barlett Sphericity Test $\chi^{2}=1.853$, df $=153$, and $\mathrm{p}<.001$. The CAS comprised of three dimensions, i.e. Evaluation, Organisation and Planning. The Cronbach Alpha internal consistency coefficient for the whole scale is .89 . One of the items in the "evaluation" dimension is "I question whether I understand the subject or not during the class" and its Cronbach Alpha internal consistency coefficient is .87. One of the items in the "organisation" dimension is "I check my tasks under the course subject while performing them" and its Cronbach Alpha internal consistency coefficient is .65. One of the items in the "planning" dimension is "I can create the conditions required to internalise the goals of the class" and its Cronbach Alpha internal consistency coefficient is .70. The three sub-scales explain $53.07 \%$ of the overall variance. The chi-square value calculated through confirmatory factor analysis for model-data fit was found to be significant, $\chi 2=151.90, \mathrm{sd}=74, \mathrm{p}<.01$. Certain fit statistics calculated through the same analysis are as follows: $(\chi 2 / \mathrm{sd})=2.05, \quad \mathrm{RMSEA}=0.064, \quad \mathrm{RMR}=0.045, \quad \mathrm{GFI}=0.92$, $\mathrm{AGFI}=0.89, \mathrm{NNFI}=0.91, \mathrm{NFI}=0.87, \mathrm{CFI}=0.93$ ).

Along with the reliability analysis performed for the extant study, the Cronbach Alpha internal consistency coefficient for the whole scale was found to be .91. The Cronbach Alpha values for the sub-scales of the scale were .85 for the sub-scale of "Evaluation", .71 for the sub-scale of "Organisation" and .80 for the sub-scale of "Planning".

\subsection{3. 'Community Service Activities Perception Scale'}

'Community Service Activities Perception Scale' developed by Demir, Kaya and Taşdan [10] was used in order to determine the perception of community service activities and to examine the faculty of education students' (randomly selected 313 from different departments) perceptions on community service activities. The data were analysed through exploratory and confirmatory factor analysis to enhance the construct validity. Internal consistency (Cronbach Alpha) co-efficiency was evaluated for the reliability of the instrument. A 33-item instrument with "Thinking Processes and Skills", "Awareness" and "Benefit" subscales was developed as a result of the analyses conducted. Cronbach Alpha internal consistency co-efficiency that explains $55,046 \%$ of the overall variance was found .93 for the first factor, .90 for the second factor, and .73 for the third factor). Confirmatory factor analysis, which has been made to examine how much the three-factor model is adjust with the data gathered, and chi-square value, which is calculated for model-data alignment, have been found meaningful $(\chi 2=1310.77, \mathrm{sd}=492, \mathrm{p}<.01)$. Some fit statistics calculated with the same analysis are like these: $(\mathrm{X} 2 / \mathrm{df})=2,66 ; \mathrm{RMSEA}=0,073 ; \mathrm{RMR}=0,085 ; \mathrm{GFI}=0,81$; $\mathrm{AGFI}=0,77 ; \mathrm{NNFI}=0,97 ; \mathrm{CFI}=0,97$. Confirmatory factor analysis of three-factor model and the rate of chi-square calculated for model-data fit have been proved to be significant with the first modification (done between M2 and M1), $\mathrm{X} 2=1238,81, \mathrm{df}=491, \mathrm{p}<01$. Some fit statistics calculated with the same analysis are like these: $(\mathrm{X} 2 / \mathrm{df})=$ 2,52; $\mathrm{RMSEA}=0,070 ; \mathrm{RMR}=0,068 ; \mathrm{GFI}=0,81$; $\mathrm{AGFI}=$ 0,$78 ; \mathrm{NNFI}=0,97 ; \mathrm{NFI}=0,96 ; \mathrm{CFI}=0,97$. Confirmatory factor analysis of three-factor model and the rate of chi-square calculated for model-data fit have been proved to be significant with the second modification (done between M24 and M23) X2 $=1174,66, d f=490, p<01$. Some fit statistics calculated with the same analysis are like these: $(\mathrm{X} 2 / \mathrm{df})=2,39 ; \mathrm{RMSEA}=0,067 ; \mathrm{RMR}=0,085 ; \mathrm{GFI}=0,81$; $\mathrm{AGFI}=0,79 ; \quad \mathrm{NNFI}=0,97 ; \quad \mathrm{NFI}=0,96 ; \quad \mathrm{CFI}=0,98$. Confirmatory factor analysis of three-factor model and the rate of chi-square calculated for model-data fit have been proved to be significant with the third modification (done between M21 and M20) X2=1244,73, df= 489, $\mathrm{p}<01$. Some fit statistics calculated with the same analysis are like these: $(\mathrm{X} 2 / \mathrm{df})=2,54 ; \mathrm{RMSEA}=0,070 ; \mathrm{RMR}=0,085 ; \mathrm{GFI}=0,81$; $\mathrm{AGFI}=0,78 ; \mathrm{NNFI}=0,97 ; \mathrm{NFI}=0,96 ; \mathrm{CFI}=0,98$. Internal consistency (Cronbach Alpha) co-efficiency (.95) was evaluated for the reliability of the instrument. A 33-item instrument with "Thinking Processes and Skills", "Awareness" and "Benefit" subscales was developed as a result of the analyses conducted. Cronbach Alpha internal consistency co-efficiency that explains 55,046\% of the overall variance was found .93 for the first factor, .90 for the second factor, and .73 for the third factor. 


\subsection{Data Analysis}

Data incomplete and incorrect coding were revised prior to analysis. Next, regression analysis of outlier analysis to examine the assumptions was done, and the analysis of Mahalanobis distance value is held out great values. The final step is variable across multiple changes (multicollinearity) variance swelling (VIF) and examined for tolerance, approaching tolerance zero, 5 large VIF, accompanied by two large variances of 0.50 , and 30 were not observed indices in great condition. As a result, deleting data sets from the observations made as a result of missing values and outlier analysis analyses were performed on participants. The study was carried out in order to explain the dependent variable multiple linear regression analysis. The dependent variable of the study, the scores of the Cognitive Awareness Scale, the arguments Community Service Activities are taken from overall and subscale scores of Perception Scale. Community Service Activities Perception Scale in which multiple linear regression analysis was conducted to determine the awareness and benefits subscale and overall scores of what extend thinking, process of cognitive skills and abilities are predicted. As input to the independent variables in this equation is determined by statistical analysis criteria, each argument is based on equality as their input in terms of what he added (Tabachnick and Fidell [48]). Whether the interpretation of the findings was significant (.05).

\section{Conclusions}

It was used Multiple Linear Regression to determine the variables predicting the metacognitive skills of prospective teachers. Following in Table 1 was given "arithmetic mean, standard deviation, and the correlation scores among the variables". In part of Findings; firstly, it was given the arithmetic mean of dependent and predictor variables, standard deviation, and descriptive scores showing the correlation matrix; then it was given the results of multiple regression analysis.

\subsection{Correlation among Variables}

In Table 1 was given arithmetic mean of used variables, standard deviation, and correlation matrix.

Table 1 shows that the arithmetic mean of dependent variables is between 49,64 and 10,67, and standard deviation is between 10,89 and 2,67. Depending upon the used five-likert scale to measure the dependent variables, it is seen that arithmetic mean is high. Arithmetic mean of independent (Predictor) variables is between 65.60 and 14.78; and standard deviation is between 14.30 and 4.47. The means of independent variables measured by five-likert scale is seen similarly high.

It is seen in Table 1 that there is a significant correlation between most of the predictor variables and dependent ones. There is no large correlation in tabulated, but there is a medium-level and significant correlation. On the other hand, there is no significant correlation between the benefit sub-scale of CAS and the evaluation and organization sub-scale of MAS.

\subsection{The Predictive Power of Sub-scales of CAS on MAS Overall Scores}

The evaluation for this part was based on Regression; the sub-scales of CAS as Predictor (Independent) Variable; MAS Overall Scores as Dependent Variable. The analysis is clearly given at Table 2 .

Table 1. The Sub-scales Scores of MAS and CAS and Arithmetic Mean, Standard Deviation and Correlation Scores referred to Predictor Variables

\begin{tabular}{|c|c|c|c|c|c|c|c|c|}
\hline Variables & $\mathrm{X}$ & Ss & 1 & 2 & 3 & 4 & 5 & 6 \\
\hline MAS Overall & 49,64 & 10,89 &, $96 * *$ &, $78 * *$ &, $84 * *$ & $68^{* *}$ &, $69^{* *}$ &, 17 \\
\hline 1.Evaluation & 24,55 & 6,39 & 1 &, $66^{* *}$ &, $73 * *$ &, $70^{* *}$ &, $68^{* *}$ &, 17 \\
\hline 2.Organization & 10,67 & 2,67 &, $66^{* *}$ & 1 &, $52 * *$ &, $39 * *$ &, $48 * *$ &, 035 \\
\hline 3.Planning & 14,42 & 3,12 &, $73 * *$ &, $52 * *$ & 1 &, $60 * *$ &, $58 * *$ &, $22 *$ \\
\hline \multicolumn{9}{|c|}{ Predictor (Independent) Variables } \\
\hline 4. Thinking Processes and Skills & 65,60 & 14,30 &, $70^{* *}$ &, $39 * *$ &, $60 * *$ & 1 &, $86^{* *}$ &, $28 * *$ \\
\hline 5. Awareness & 37,12 & 10,12 &, $68^{* *}$ &, $48^{* *}$ &, $58 * *$ &, $86^{* *}$ & 1 &, $28 * *$ \\
\hline 6. Benefit & 14,78 & 4,47 &, 17 &, 035 &, $22 *$ &, $28 * *$ &, $28 * *$ & 1 \\
\hline
\end{tabular}

** $\mathrm{P}<.001$

Table 2. Scores of Multiple Linear Regression referred to MAS Overall Scores and Predictor (Independent) Variable

\begin{tabular}{ccccccccc}
\hline Variable & B & St Error B & $\beta$ & t & P & Binary & Partial \\
Constant & 17,76 & 4,04 & - & 4,39 &, 000 & - & - \\
Thinking Processes and Skills &, 257 &, 108 &, 337 & 2,38 &, 019 &, 681 &, 236 \\
Awareness &, 445 &, 152 &, 413 & 2,92 &, 004 &, 691 &, 286 \\
Benefit &,- 099 &, 183 &,- 041 &,- 541 &, 590 &, 174 &,- 055 \\
& $R=0.712 ;$ & $R^{2}=0.508 ;$ & Corrected $R^{2}=0.492 ;$ & $F_{(3,96)}=32,976 ;$ & $p=.000$ & & & \\
\end{tabular}


Table 2 shows that all predictor (independent) variables explain significantly $51 \%$ of the MAS Overall Scores $\left(\mathrm{R}=.712, \mathrm{R}^{2}=.508, \mathrm{~F}(3-96)=32.976, \mathrm{p}<.001\right)$. According to the standardized regression coefficient $(\beta)$, the regressors are in order of importance between predictor (independent) variables and its influence over metacognition awareness skills: awareness (.413), thinking processes and skills (.337), and benefit $(-, 041)$.

Depending upon the results of t-test to determine the significance of regression coefficient; the all sub-scales except from benefit of CAS explain significantly the overall scores of MAS.

\subsection{The Predictive Power of Sub-scales of CAS on the Evaluation Sub-scale of MAS}

The evaluation for this part was based on Multiple Linear Regression; the sub-scales of CAS as Predictor (Independent) Variable; MAS Overall Scores as Dependent Variable. The analysis is clearly given at Table 3.

Table 3 shows that all predictor (independent) variables explain significantly $52 \%$ of the MAS Overall Scores $\left(\mathrm{R}=.722, \mathrm{R}^{2}=.521, \mathrm{~F}(3-96)=34.788, \mathrm{p}<.001\right)$. According to the standardized regression coefficient $(\beta)$, the regressors are in order of importance between predictor (independent) variables and its influence over metacognition awareness skills: thinking processes and skills (.419), awareness (.341), and benefit $(-, 046)$.

Depending upon the results of $t$ test to determine the significance of regression coefficient; the all sub-scales except from benefit of CAS explain significantly the overall scores of metacognition scale.

\subsection{The Predictive Power of Sub-scales of CAS on the Organization Sub-Scale of MAS}

The evaluation for this part was based on Multiple Linear Regression; the sub-scales of CAS as Predictor (Independent) Variable; the organization sub-scale scores of MAS as Dependent Variable. The analysis is clearly given at Table 4.

As seen in Table 4, all predictor (independent) variables explain significantly $24 \%$ of the MAS Overall Scores $\left(\mathrm{R}=.492, \mathrm{R}^{2}=.242, \mathrm{~F}(3-96)=10.228, \mathrm{p}<.001\right)$. According to the standardized regression coefficient $(\beta)$, the regressors are in order of importance between predictor (independent) variables and its influence over organization sub-scale: awareness (.547), thinking processes and skills $(-, 041)$, and benefit $(-, 109)$.

Depending upon the results of $t$ test to determine the significance of regression coefficient; while the thinking processes, skills and benefit sub-scales of CAS do not explain significantly the organization sub-scale of MAS; the awareness sub-scale of CAS explains significantly the organization sub-scale of MAS.

\subsection{The Predictive Power of Sub-scales of CAS on the Planning Sub-Scale of MAS}

The evaluation for this part was based on Multiple Linear Regression; the sub-scales of CAS as Predictor (Independent) Variable; the planning sub-scale scores of MAS as Dependent Variable. The analysis is clearly given at Table 5.

Table 3. Scores of Multiple Linear Regression referred to Evaluation Sub-Scale of MAS and Predictor (Independent) Variable

\begin{tabular}{|c|c|c|c|c|c|c|c|}
\hline Variable & B & St Error B & $\beta$ & $\mathrm{t}$ & $\mathrm{P}$ & $\begin{array}{c}\text { Binary } \\
r\end{array}$ & $\begin{array}{c}\text { Partial } \\
\mathrm{r}\end{array}$ \\
\hline Constant & 5,221 & 2,34 & - & 2,22 & ,028 & - & - \\
\hline Thinking Processes and Skills &, 188 & 062 & ,419 & 3,00 & ,003 &, 700 & ,293 \\
\hline Awareness & ,216 & ,088 &, 341 & 2,45 & ,016 & ,689 & ,243 \\
\hline Benefit &,- 066 &, 106 &,- 046 &,- 628 & ,532 &, 172 &,- 064 \\
\hline$R=0.722$; & $R^{2}=0.521$ & Corrected $R^{2}=0.506$ & $F_{(3,96)}=$ & $788 ;$ & & & \\
\hline
\end{tabular}

Table 4. Scores of Multiple Linear Regression referred to Organization Sub-Scale of MAS and Predictor (Independent) Variable

\begin{tabular}{|c|c|c|c|c|c|c|c|}
\hline Variable & B & St Error B & $\beta$ & $\mathrm{t}$ & $\mathrm{P}$ & $\begin{array}{c}\text { Binary } \\
\mathrm{r}\end{array}$ & $\begin{array}{c}\text { Partial } \\
\mathrm{r}\end{array}$ \\
\hline Constant & 6,782 & 1,229 & - & 5,517 &, 000 & - & - \\
\hline Thinking Processes and Skills &,- 008 &, 033 &,- 041 &,- 235 &, 814 & 398 &,- 024 \\
\hline Awareness &, 144 &, 046 &, 547 & 3,120 &, 002 & , 480 & ,303 \\
\hline Benefit &,- 065 &, 056 &,- 109 & $-1,171$ &, 245 & ,035 &,- 119 \\
\hline$R=0.492$; & $R^{2}=0.242$ & \multicolumn{6}{|c|}{ Corrected $R^{2}=0.219 ; \quad F_{(3,96)}=10,228 ; \quad p=.000$} \\
\hline
\end{tabular}

Table 5. Scores of Multiple Linear Regression referred to Planning Sub-Scale of MAS and Predictor (Independent) Variable

\begin{tabular}{|c|c|c|c|c|c|c|c|}
\hline Variable & B & St Error B & $\beta$ & $\mathrm{t}$ & $\mathrm{P}$ & $\begin{array}{c}\text { Binary } \\
r\end{array}$ & $\begin{array}{c}\text { Partial } \\
r\end{array}$ \\
\hline Constant & 5,772 & 1,298 & - & 4,446 &, 000 & - & - \\
\hline Thinking Processes and Skills &, 077 &, 035 &, 351 & 2,218 &, 029 & 600 & ,221 \\
\hline Awareness & 084 & ,049 & 274 & 1,730 &, 087 &, 589 &, 174 \\
\hline Benefit &, 033 &, 059 & 047 &, 556 &, 580 & ,226 &, 057 \\
\hline$R=0.618$ & $R^{2}=0.382$ & Corrected $R^{2}=0.363 ;$ & \multicolumn{5}{|c|}{$F_{(3,96)}=19,818 ; \quad p=.000$} \\
\hline
\end{tabular}


As seen in Table 5, all predictor (independent) variables explain significantly $38 \%$ of the MAS Overall Scores $\left(\mathrm{R}=.618, \mathrm{R}^{2}=.382, \mathrm{~F}(3-96)=19.818, \mathrm{p}<.001\right)$. According to the standardized regression coefficient $(\beta)$, the regressors are in order of importance between predictor (independent) variables and its influence over planning sub-scale: thinking processes and skills (.351), awareness (.274), and benefit $(, 047)$.

Depending upon the results of t-test to determine the significance of regression coefficient; while the thinking processes and skills only of CAS explain significantly the planning sub-scale of MAS; the variables of awareness and benefit do not have significant influence.

\subsection{The Predictive Power of the Overall Scores of CAS on the Overall Scores of MAS}

The evaluation for this part was based on Multiple Linear Regression; the overall scores of CAS as Predictor (Independent) Variable; the overall scores of MAS as Dependent Variable. The analysis is clearly given at Table 6.

Table 6. Scores of Multiple Linear Regression referred to Overall Scores of MAS and Predictor (Independent) Variable

\begin{tabular}{ccccccccc}
\hline Variable & $\mathrm{B}$ & $\begin{array}{c}\mathrm{St} \\
\text { Error }\end{array}$ & $\beta$ & $\mathrm{t}$ & $\mathrm{P}$ & $\begin{array}{c}\text { Binary } \\
\mathrm{B}\end{array}$ & $\begin{array}{c}\text { Partial } \\
\mathrm{r}\end{array}$ \\
Constant & 14,547 & 3,775 & - & 3,854 &, 000 & - & - \\
Overall &, 299 &, 031 &, 693 & 9,507 &, 000 &, 693 &, 693 \\
$R=0.693 ;$ & $R^{2}=0.480 ;$ & Corrected $R^{2}=0.474 ;$ & $F_{(1,98)}=90,391 ;$ \\
$p=.000$ & & & \\
\hline
\end{tabular}

As seen in Table 6 , all predictor (independent) variable explains significantly $48 \%$ of the MAS Overall Scores $\left(\mathrm{R}=.693, \mathrm{R}^{2}=.480, \mathrm{~F}(1-98)=90.391, \mathrm{p}<.001\right)$. According to the standardized regression coefficient $(\beta)$, the regressors are comparative importance between predictor (independent) variables and its influence over overall scores of MAS: $(, 693)$

Depending upon the results of $t$ test to determine the significance of regression coefficient; the overall scores of CAS explain significantly the overall scores of MAS.

\subsection{Discussion, Results and Suggestions}

Based on the t-test results related to the significance of regression coefficient, overall scores of Metacognition Awareness Scale (MAS) scale explain significantly the sub-scales, awareness and thinking processes and skills of 'Community Service Activities Perception Scale (CAS)'. MAS comes to one's minds as the process of learning to learn and thinking to think. In such a process, the existence of social processes and interaction will be inevitable. Hence, within this process, community service activities give students opportunities to improve various skills in subjects such as team building, leadership, problem solving, communication, organization and time use. (Tucker, McCarthy, Hoxmeier, \& Lenk, 1998; cited by Shiarella,
McCarthy and Tucker [42]). It is an expected finding that such a process contributes to explain significantly the process of metacognitive awareness characterizing that individual is aware of knows, checks and directs his/her own cognitive processes (Meichenbaum, 1986, cited by Boyce, Baksa, Burruss, Sher, Johnson [2]. In a similar way, Lemons, Swan, Carberry, Jarvin, (2011) also examined effects of learning by serving the public upon the process of students' metacognitive awareness during the duty of engineering teaching design in their study. In addition, they recognized that they provided positive contribution in the matter of correct work analyze and skill of clear strategic planning. Overall scores of Metacognition Awareness Scale (MAS) scale explain significantly the sub-scales, awareness and thinking processes and skills of 'Community Service Activities Perception Scale'. It is not a surprising finding that metacognitive awareness explains individual himself/herself and his/her learning process and self-assessment aspect because the opportunities of critical and reflective thinking are provided to students in social practices during the process of community service activities. Community service learning and service learning also enable students to develop a number of their skills. Thanks to community service activities, students improves their skills in such subjects as team work, leadership, conflict resolution, communication and time management (Tucker, McCarthy, Hoxmeier and Lenk, 1998). At the same time, in such process these students can also form their awareness of being able to evaluate their own perfection and features.

The ability of metacognitive awareness is both located in the basis of thinking and also involves all the thinking skills. They are all located in the concept metacognition for a person to decide his/her steps working, develop an attitude about that issue, plan duty or issue in his/her mind, review his/her plan permanently, and organize defectives consistently. In this process, individuals gain much better control about thinking and feeling processes by reflecting and assessing their own thinking processes (Carr and Borkowski, 1986, cited by Gallagher [21]). It was found that the scores of organization sub-scale contributes to explain significantly the awareness sub-scale characterizing that individual is aware of or knows, checks and directs his/her own cognitive processes. Also in the community service activities, being aware of social activities makes a direct relation with the dimension of relation and organization of metacognitive awareness. As a matter of fact, Schelbe, Petracchi and Weaver [39] touched on the significance of metacognitive awareness process in the process of social activity in the community service activities in their study.

When we look at the results of some studies related to community service activities, it is clear that they increase social and intellectual abilities (Klute and Billig 2002); relations are with social and cultural heritage (Billig, Meyer, and Hofschire 2003). Herewith, these provide awareness to social problems and contribute to rise knowledge of civil participation (Melchior and Bailis 2002) and improve the 
ability of problem solving and moralization (Eyler, Root and Giles 1999). Then, these raise esteemed and respectful attitudes against different races much more (Stewart [35]; Stewart and Bai [46]). It has been seemed that they also enhance expectation of political participation and perfection (Billig, Root, and Jesse 2005) and advance a developed participant perfection and skills which are necessary for citizenship participation (Althof and Berkowitz 2006) (cited by Stewart, 2012, 28). Thus it is not a surprising finding that the practice having such a process explains planning points of metacognitive awareness scale meaningfully. However, overall scores of Metacognition Awareness Scale (MAS) scale explain significantly the sub-scales, awareness and thinking processes and skills of 'Community Service Activities Perception Scale (CAS)'. In a similar way, Karaman [26] also found that community service activities had contribution to the occurrence of thinking systems among program participants at the end of his study. In addition to this, community activities practices flourish teacher candidates' personalities by contributing them to grow social citizen conscious by which they could tackle social problems, have leadership traits, and have developed the sense of responsibility (Şeker [47]). Gürol and Özercan [23] also searched the effects of community service activities lectures over students in the faculty of education; consequently, they confirmed that these activities done in the lectures were effective to improve teacher candidates' leadership traits and to get socialized. In such a process, it is not an amazing process that the overall dimension of the scale of community service activities predicts the overall dimension of the scale of metacognitive awareness meaningfully. Because community service activities is an applied course that prospective teachers form within the context of projects, such a practice gives students opportunity to design a project and develop themselves in this matter. In this framework, metacognition awareness develops the person himself on the knowledge of cognitive awareness and knowledge about the teaching process on their own; research organizations; additionally, improve their organization and inquiry skills so as to be an effective project developer.

When it is thought that the course of community service activities are also a lesson formed in the context of projects, it has been found that the overall points of two scales predict the other one. Thus in the study done by Molee, Henry, Sessa [33], critical thinking and reflective activities develop in a positive way with learning activities by serving the public. Drawing upon these results, in general it is seen that community service activities explain significantly metacognitive awareness and its subscales.

In accordance with the findings of the study, it can be suggested that studies of project education supporting the process and skills of metacognitive awareness in the syllabus of community service activities in department program in the Faculty of Education should be touched on and practice-oriented activities should be carried on. Furthermore, it can also be suggested that instructors should consult students about how to reflect abilities of metacognitive awareness to projects that will be prepared, topics should be chosen among extant functional topics in behalf of the public which will develop process and skills of senior thinking, and in this respect it should be cooperated with non-governmental organizations.

\section{REFERENCES}

[1] Açıkgöz, Ö. Effective Learning and Teaching, İzmir: Kanyılmaz Press, 1996.

[2] Boyce, N.L., Van Tassel-Baska, Burruss J. D., Sher B.T. ve Johnson D.T. A problem based curriculum: Parallel learning opportunities for students and teachers. Journal for the Education of the Gifted 20 (4), ss. 363-379, 1997

[3] Borg, W. R., \& Gall, M. D. Educational research. New York: Longman, 1989.

[4] Bloom, B. S. (Ed.). Taxonomy of educational objectives. Handbook I: Cognitive domain. New York: McKay, 1956.

[5] Brown, A. L., Bransford, J. D., Ferrara, R. A., \& Campione, J. C. (1983). Learning, remembering, and understanding. In P. H. Mussen (Series Ed.), J. H. Flavell \& E. M. Markman (Eds.), Handbook of child psychology: Vol. 3. Cognitive development (pp. 77-166). New York: Wiley

[6] Bringle R, Hatcher J. A. Innovative practices in service-learning and curricular engagement. New Directions for Higher Education 147: 37-46, 2009.

[7] Çetinkaya, P. Metacognition: its assessment and relationship with reading comprehension, achievement, and aptitude for sixth grade student', M.A. Thesis, Bogaziçi University, The Institute of Social Sciences, İstanbul, 2000.

[8] Demir, Ö. The effect of metacognitive strategies instructed through cognitive coaching on students? Epistemological beliefs, metacognitive skills, academic achievement and the retention of these in 6th grade social studies course, Doctoral Dissertation, Çukurova University, Graduate School of Social Sciences, Adana, 2009.

[9] Demir, Ö. A validation and reliability study of the metacognition scale in Turkey. Global Journal of Human Social Science Linguistics \& Education 13 (10), 27-35, 2013.

[10] Demir, Ö., Kaya, H. İ. and Taştan, M. A validation and reliability study of community service activities scale in Turkey: A social evaluation. Educational Research and Reviews 9 (14), 456-465, 2014.

[11] Demirel, Ö. Education Terms Dictionary. Ankara: Usem Press, 1993.

[12] Doğanay, A. Ders dinleme sırasında bilişsel farkındalıkla ilgili stratejilerin kullanımı. Çukurova Üniversitesi Ĕ̈itim Fakültesi Dergisi 2 (15), ss. 34-42, 1997.

[13] Draper A. J. Integrating project-based service-learning into an advanced environmental chemistry course. J Chem Education 81(2): 221-224, 2004

[14] Erden, M. ve Akman, Y. Eğitim Psikolojisi: Gelişim, 
Öğrenme ve Öğretme. (3.bask1). Ankara: Arkadaş Press, 1996.

[15] Elma C K, Kıroğlu A., Long K., Tigris E. M. and Palavan Ö. Course in candidate teachers' perceptions of community services. Theory and Practice of Educational Administration 16(2): 231-252, 2010.

[16] Flavell, J. H. Development of children's knowledge about the mental world. International Journal of Behavioral Development, 24, 15-23, 2000.

[17] Flavell, J. H., \& Miller, P. H. Social cognition. In W. Damon (Series Ed.), D. Kuhn \& R. S. Siegler (Eds.), Handbook of child psychology: Vol. 2. Cognition, perception, and language (5th ed., pp. 851-898). New York: Wiley, 1998.

[18] Flavell, J. H., Green, F. L., \& Flavell, E. R. Young children's knowledge about thinking. Monographs of the Society for Research in Child Development, 60 (1, Serial No. 243), 1995b.

[19] Flavell, J. H., Miller, P. H., \& Miller, S. A. Cognitive development (4th ed.). Upper Saddle River, NJ: Prentice Hall, 2002.

[20] Flavell, J. H. Metacognition and cognitive monitoring: A new area of cognitive-developmental inquiry. American Psychologist, 34, p. 906-911, 1979.

[21] Gallagher, S. A. Problem based learning: Where did it come from, what does it do, and where is it going. Journal of the Education of the Gifted, 20(4), 332-362, 1997.

[22] Gökçe N. Social sciences teachers' reviews on the applications of community service. International Journal of Human Sciences 8(2): 176-194, 2011.

[23] Gürol, A. \& Özercan, M. G. Topluma hizmet uygulamas1 dersinin uygulanmasına ilişkin görüşlerin belirlenmesi. 9. Ulusal Sinıf Öğretmenliği Eğitimi Sempozyumu içinde (s. 539-544), Elazı̆̆, 2010.

[24] Hatcher-Skeers, M. and Aragon, E. Combining active learning with service learning: A student-driven demonstration project. $J$ Chem Education 79(4): 462-464, 2002.

[25] Horzum B. and Bektas M. Authentic learning community service and satisfaction lesson are teachers' attitudes toward impact of course. Kastamonu Education Journal 20(1): 341-360, 2012.

[26] Karaman, C. Community Service Learning and the Emergence of Systems Thinking: A Teacher Education Project in an Urban Setting in Turkey. Syst Pract Action Res, 27, 485-497, 2014.

[27] Kalivas J. H. A service-learning project based on a research supportive curriculum format in the general chemistry laboratory. J Chem Education 85(10): 1410-1415, 2008.

[28] Kuhn, D. Metacognitive development. In L. Balter and C. S. TamisLeMonda (Eds.) Child psychology: A handbook of contemporary issues. Philadelphia, PA: Psychology Press, 1999.

[29] Lee, C. B., Teo, T. and Chai, C. S. Profiling pre-service teachers' awareness and regulation of their own thinking: Evidence from an Asian country. Teacher Development 14(3), 295-306, 2010.

[30] Louca, L. The concept and instruction of metacognition.
Teacher Development, 7(1), ss. 9-30, 2003.

[31] Namlu, A. G. Bilişötesi Öğrenme Stratejileri Ölçme Aracının Geliştirilmesi: Geçerlilik ve Güvenirlik Çalışması. Anadolu Üniversitesi, Sosyal Bilimler Dergisi, 4(2), ss.123-141, 2004.

[32] Nielsen, S. Strategies and Self-Efficacy Beliefs in Instrumental and Vocal Individual Practice: A Study of Students in Higher Music Education. Psychology of Music 32 (4), 418-431, 2004.

[33] Molee, L. M., Henry, M. E., Sessa, V. I., McKinney-Prupis, E. Assessing Learning in Service-Learning Courses through Critical Reflection. Journal of Experiential Education 33 (3), 239-257, 2010.

[34] Moshman, D. Cognitive development beyond childhood. In W. Damon (Series Ed.), D. Kuhn \& R. S. Siegler (Eds.), Handbook of child psychology: Vol. 2. Cognition, perception, and language (5th ed., pp. 947-978). New York: Wiley, 1998.

[35] Özsoy, G. and Günindi, Y. Prospective preschool teachers' metacognitive awareness. Elementary Education Online 10(2), 430-440, 2011.

[36] Pinto, M. A., Iliceto, P. and Melogno, S. Argumentative Abilities in Metacognition and in Meta-linguistics: A Study on University Students. European Journal of Psychology of Education 27 (1), 35-58, 2012.

[37] Öğülmüş, S. Contribution of Education Faculties to Social Life in the Context of Community Service. Ankara: Ankara University, Faculty of Educational Sciences Publications, 2006.

[38] Saran M., Coşkun G., İnal Z., F. and Aksoy Z. Responsible for the development of social awareness in universities hood: A study on the course Ege University, community service applications. Yaşar University Journal 22(6): 3732-3747, 2011.

[39] Schelbe, L., Petracchi, H. and Weaver, A. Benefits and Challenges of Service-Learning in Baccalaureate Social Work Programs. Journal of Teaching in Social Work, 34 (5), 480-495, 2014

[40] Semerci, Ç. ve Elaldı, Ş. Tıp Fakültesi Öğrencilerinin Üstbilişsel İnançları. Uluslararası Eğitim Programları ve Öğretim Çalışmaları Dergisi 2011 Vol.: 1, Number: 2, 37-49, 2011.

[41] Shantz, C. U. Social cognition. In P. H. Mussen (Series Ed.), J. H. Flavell \& E. M. Markman (Eds.), Handbook of child psychology: Vol. 3. Cognitive development (pp. 495-555). New York: Wiley, 1983.

[42] Shiarella A. H., Mccarthy A. M. and Tucker M. L. Development and construct validity of scores on the Community Service Attitudes Scale. Educational and Psychological Measurement 60: 286, 2000.

[43] Sönmez Ö.F. Social studies teachers' attitudes towards public service applications, class-size, and evaluation of recovery. The Black Sea Journal of Social, Sciences 2(2): 53-71, 2010.

[44] Schneider, W., \& Bjorklund, D. F. Memory. In W. Damon (Series Ed.), D. Kuhn \& R. S. Siegler (Eds.), Handbook of child psychology: Vol. 2. Cognition, perception, and language (5th ed., pp. 467-521). New York: Wiley, 1998.

[45] Stewart T. Community-based service-learning for youth empowerment in Palestine. The Educational Forum 76: 25-40, 2009. 
[46] Stewart, T., \& Bai, H. Community service self-efficacy: Comparative analyses among academically talented youth enrolled in a summer academic program. Gifted Education International, 27(2), 149-160, 2010.

[47] Şeker, A. Topluma Hizmet Uygulamalari. Ankara: Nobel Yayınlar1, 2009.

[48] Tabachnick B. G. and Fidell L. S. Using multivariate statistics. Fourth Edition. New York Harper: Collins Publishers, 2001.

[49] Tucker M. L., McCarthy A. M., Hoxmeier J. A. and Lenk M. M. Community service learning increases communication skills across the business curriculum. Business Communication Quarterly 61: 89-100, 1998.

[50] Uğurlu Z. and Kıral E. Prospective teachers of the course, its processes and its applications in service to the community views on the achievements. The $2^{\text {nd }}$ International Conference on New Trends in Education and their Implications 720-734, 2011.

[51] Woolley, J. D., \& Boerger, E. A. Development of beliefs about the origins and controllability of dreams. Developmental Psychology, 38, 24-41, 2002.

[52] Y1lmaz, A. E. Examination of Metacognitive Factors in Relation to Anxiety and Depressive Symptomps: A Crosscultural Study. [Üstbilişsel faktörlerin kaygı ve depresyon semptomları açısından incelenmesi: Kültürlerarası bir çalışma]. Doktora Tezi. The Graduate School of Social Sciences of Middle East Technical University, 2007.

[53] Yılmaz K. Social responsibility and community service lecture of education faculties: A qualitative research. Theoretic Education Sciences 4(2): 86-108, 2011. 